\title{
КРЕДИТНИЙ МОНТТОРИНГ В КОМЕРЦІЙНИХ БАНКАХ ЯК СПОСІБ ПОПЕРЕДЖЕННЯ ВИНИКНЕННЯ ПРОБЛЕМНОЇ ЗАБОРГОВАНОСТІ
}

\begin{abstract}
Анотація. Розглянуто сутність та зміст поняття «кредитний моніторинг». Наведено параметри і змістові характеристики терміну «кредитні ризики». Досліджено фактори виникнення проблемної заборгованості за кредитними договорами та систематизовано критерії, що впливають на стабільну платоспроможність кліентів за кредитними договорами. Проаналізовано ключові засади формування методології кредитного моніторингу в Українських банках. Обтрунтовано потребу удосконалення системи кредитного моніторингу в вітчизняних банках. Доведено практичну необхідність створення і функціонування у вітчизняних комерційних банках підрозділу кредитного моніторингу. Аргументовано диспозицію кредитного моніторингу банківськими установами, за якою його слід розглядати механізмом попередження виникнення проблемної заборгованості, інструментальним засобом покращення якості кредитних портфелів.
\end{abstract}

Ключові слова: кредитний моніторинг, кредитні ризики, кредитний портфель, кредитна діяльність, непрацюючі кредити, контроль, проблемна заборгованість.

Yaremko Ihor, Zavoritnii Mykola Lviv Polytechnic National University

\section{CREDIT MONITORING IN COMMERCIAL BANKS AS A WAY TO PREVENT THE OCCURRENCE OF PROBLEM DEBT}

Summary. The essence and content of the concept of "credit monitoring" and its disposition in modern conditions of servicing the banking sector of the crisis economy and the decrease in the solvency of borrowers are considered. Parameters and content characteristics of the term "Credit Risks" are given to such interconnections with financial rays of the banking institution. The factors of the emergence of problem debt by loan agreements and systematized criteria that affect the stable solvency of clients by credit contracts are investigated. The main factors of the emergence of problem debt are given, in particular due to a decrease in revenue by subjects of a real economy, which causes a decrease in the possibilities of stable repayment of credit debt. It is argued that especially the creation of a credit monitoring department is provided when not all enterprises during the pandemic can support the habitual profit. Therefore, a preventive function corresponds to this banking unit, since today, as it never has the need to carry out rigid monitoring banks in the quality of the financial state of the borrower and the implementation of all the terms of the loan agreement, with the aim of minimizing credit risks. The key principles of forming a credit monitoring methodology in Ukrainian banks are analyzed. The article presents the main functions of credit monitoring, analyzes the preconditions for the emergence of problem debt and evaluated the dynamics of changes in the share of NPL in the sectors of Ukrainian banks in the context of banks with a state share, private capital banks and "PrivatBank". On the basis of processed banking information, a group of problem debtors is classified and an analytical assessment of each of these groups is provided. On the basis of processed theoretical and research sources and directly official banking information, the need to improve the system of credit monitoring in domestic banks is substantiated. The practical necessity of creating and functioning in domestic commercial banks of the subsection of loan monitoring is proved. The disposition of loan monitoring by banking institutions, which should be considered a mechanism for preventing problematic debts, an instrumental means to improve the quality of loan portfolios, is argued. Focused on correctly prescribed Credit Treaty in Bank, which serves as an additional tool to monitor the financial condition of the client and reduces the risk of unpredictable situations by analyzing and monitoring the activities of the loan transaction.

Keywords: credit monitoring, credit risks, credit portfolio, credit activities, non-performing loans, control, problem debt.

$\Pi^{2}$ остановка проблеми. Розвиток банківського сектора, його адаптація до сучасних умов кризового суспільно-економічного середовища, пониження платоспроможності суб’єктів фінансових відносин має велике значення для стабілізації фінансової ситуації в країні як на мікро-, так і на макроекономічних рівнях. Діяльність банків, як і будь яка інша комерційна діяльність в умовах світової пандемії супроводжуеться ризиками. Традиційно основну частину свого прибутку банківські установи отримують від надання кредитів суб'єктам економічної діяльності, про те завжди існуе ймовірність, що навіть надійний партнер не зможе погасити взятих на себе фінансових обов'язків. У сучасних умовах ця проблематика набувае дедалі більшого поглиблення, а тому для попередження таких ситуацій у комерційних банках і створюють підрозділ кредитного моніторингу. Про те ,як показуе практика діяльності банків у цій сфері, в останній період виникає потреба у побудові більш адаптивної системи кредитного моніторингу.

Підвищений інтерес банків до розвитку власної системи моніторингу кредитних ризиків пов'язаний зі високим обсягом проблемних кредитів у портфелях вітчизняних банків, питома вага яких стає недостатньо визначеною в оглядовий період. Аналіз діяльності комерційних

${ }^{1}$ ORCID: https://orcid.org/0000-0003-3556-0609 
банків свідчить, про покращення фрінансового стану багатьох банків та зменшення частки непрацюючих кредитів (NPL) за останні роки. Хоча навіть зараз частка NPL досить висока і сягає 41,0\% на початку 2021 р. Такий високий показник є результатом кредитної експансії минулих років, коли права кредиторів були недостатньо захищені, а стандарти оцінювання клієнтів що бажали взяти позику були досить низькими. Позитивні зміни спричинені інтенсивним продажем та реструктуризацією проблемної заборгованості. Найбільша частка проблемних кредитів, близько 75\%, сконцентровано в держаному банківському секторі (рис. 1), де існують певно проблеми з кредитним моніторингом.

Виникнення проблемної заборгованості спричинено фрінансовими труднощами, зокрема зниженням виручки, зміною політичної або економічної ситуації в країні та світі. Особливо це актуально зараз коли не всі підприемства під час пандемії можуть підтримувати звичний рівень прибутку. Саме тому, сьогодні як ніколи виникає необхідність проведення банками жорсткого моніторингу за якістю фінансового стану позичальника та виконанням ним усіх умов кредитного договору, з метою вчасного проведення заходів мінімізації кредитних ризиків. Для оптимального фрункціонування банку у кризовий період важливо якісно проводити кредитний моніторинг клієнтів та оперативно реагувати як на погіршення їх фрінансових станів, так і на невиконання ними не фінансових (додаткових) умов кредитних договорів. Ключовим моментом успішного кредитного моніторингу є оперативне отримання актуальної фінансової інформації та своєчасний іiі аналіз. Ефективний контроль за повним циклом кредиту - від його видачі до погашення - забезпечує стабільне отримання прибутків банківською установою. Впровадження у практику процесів проведення дієвого кредитного моніторингу потребує раціональних процесів контролю, як інструментальної складової моніторингової системи.

Аналіз останніх досліджень і публікацій. Дослідженнями процесу кредитного моніторин- гу банківських клієнтів присвячено багато праць вітчизняних та зарубіжних науковців, зокрема: Т. Болгар, В. Вітлінський, К. Д’яконова, О. Дзюблюк, С. Сгоричевої, О. Колодізєва, Т. Косова, А. Мороз, Н. Рогожнікової, Л. Примостка, В. Сидоренко, I. Сало, С. Фроста та ін. Однак питання едрективного використання кредитного моніторингу в комерційних банках, як спосіб попередження виникнення проблемної заборгованості у вітчизняній науковій літературі, недостатньо досліджено. Це обумовлюе потребу подальших досліджень цієї складової управління банківськими установами.

Мета статті. Метою статті $є$ розгляд основних принципів фрункціонування системи кредитного моніторингу в банках України, аналіз існуючих основ реалізації кредитного моніторингу як складової системи внутрішнього контролю, яка сприятиме максимальній мінімізації витрат ресурсів, оперативній реакщії на зміни в фрінансовому стані позичальників та оперативному вирішенню ситуацій що можуть в майбутньому призвести до виникнення проблемної заборгованості. Пропонування шляхів удосконалення деяких аспектів методичного забезпечення для підвищення ефрективності і практичної дієвості кредитного моніторингу.

Виклад основного матеріалу. У зв'язку з останніми подіями в країні та світі банківській сдрері може загрожувати хвиля неплатежів по кредитним операціям, така ситуація була характерною для більшості економічних криз які переживала Україна. Банківська сорера ще не повністю нівелювала вплив попередніх криз, оскільки зараз хоч i найнижча частка не працюючих кредитів за останні кілька років, про те вона ще й досі значна. I з часом проблема неплатежів може зрости і досягти рівня попередніх років.

В таких умовах значно посилюеться значення кредитного моніторингу, за допомогою якого банк може відстежувати зміни у фінансовому стані своїх клієнтів, їх платоспроможності і приймати рішення у випадку погіршення ситуації. Таким чином суттю кредитного моніторингу є безперервний контроль за процесом кредитування та обслуговуванням кредиту, з метою зменшен-

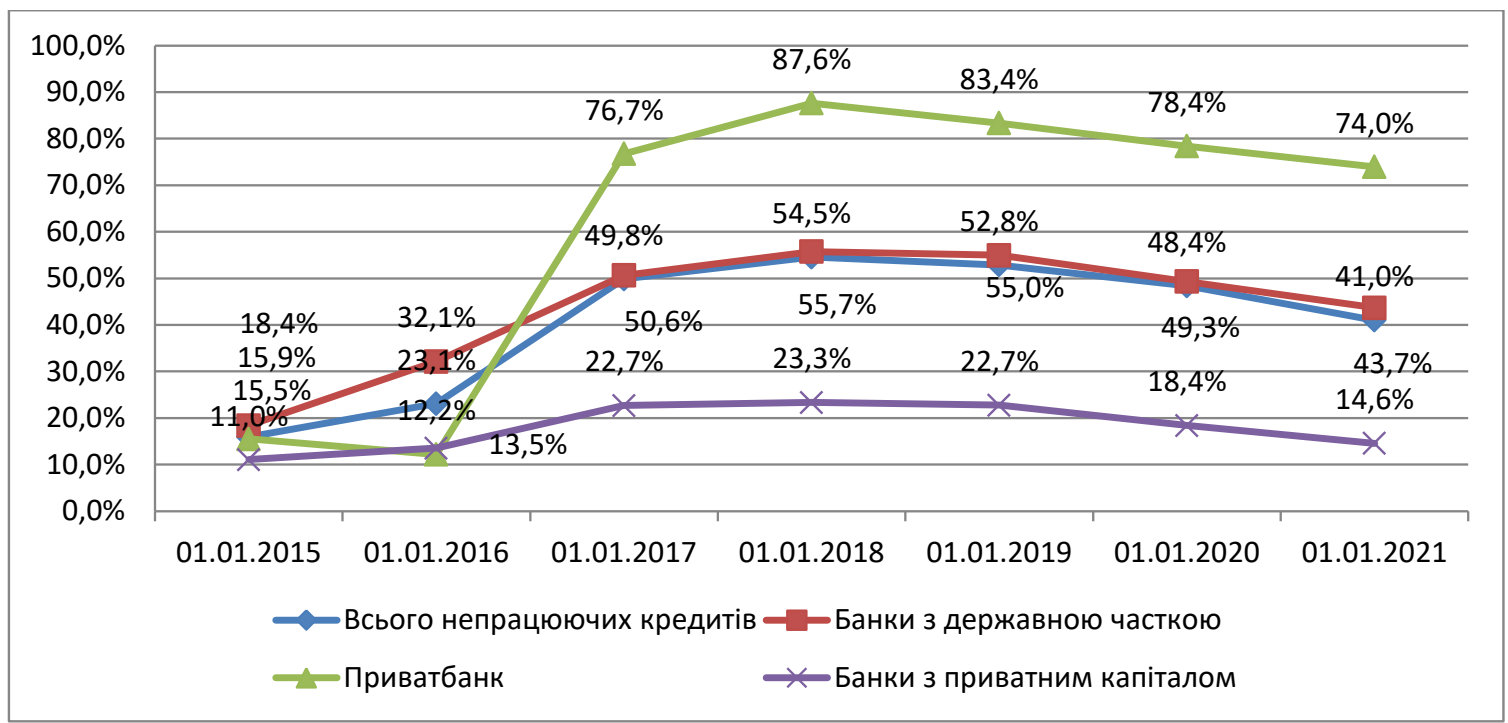

Рис. 1. Динаміка зміни частки NPL у секторах Українських банків 
ня кредитних ризиків що бере на себе кредитор при наданні позики. Кредитний моніторинг по своїй суті трудомісткий та безперервний процес, який вимагає для ефективного та безперервного фрункціонування значних фрінансових витрат та залучення достатньої кількості людських ресурсів. Українські банки намагаються утримувати рівень інтенсивності кредитного моніторингу пропорційним до їх прогнозованих ризиків. Така стратегія дозволяє організувати кредитний моніторинг з найменшими витратами, хоча недостатній рівень може призвести до набагато більших як збитків банку. Однак, також очевидно що надлишковий контроль за невеликими кредитними операціями не вигідний, з цією метою банківські установи розподіляють оцінку кредитних ризиків на портфельну та індивідуальну, що дозволяе приділяти особливу увагу моніторингу так званих "корпоративних» клієнтів, погіршення фінансового стану яких може напряму вплинути на зниження рівня дохідності банку.

При наданні кредитних коштів суб'єктам господарювання співвідношення розмірів кредитних ризиків до можливих доходів банку може бути різним, про те класичною є ситуація коли при високих кредитних ризиках банки отримують високі очікувані доходи. Наведена ситуація є не єдиною, так як при неправильному або недостатньому моніторингу кредитів трапляється зростання ризиків 3 одночасним зменшенням доходів банку. Саме тому дослідження сутності кредитного моніторингу є не від'ємним від поняття кредитного ризику. Кредитний ризик - це ризик, що характеризує можливе відхилення в одинищю часу фрактичного грошового потоку платежів клієнта, спрямованих на погашення заборгованості, процентів та комісій, від очікуваного грошового потоку, що клієнт повинен направити до банку відповідно до умов укладеного кредитного договору [2].

З'ясувавши суть кредитного моніторингу та розглянувши поняття кредитного ризику варто зсувати передумови виникнення проблемної заборгованості, умовно їх можна розділити на зовнішні та внутрішні. Внутрішні фрактори зазвичай з'являються ще на стадії прийняття рішення про видачу кредитних коштів, такі як: ліберальне ставлення до клієнта під час аналізу його заявки, неуважність або халатність при проведенні оцінки кредитоспроможності, завищена ощінка забезпечення кредиту, неповне або не коректне висвітлення у кредитному договорі умов, які представляють інтереси банку, низький рівень кредитного моніторингу під час обслуговування кредиту, зміни в внутрішньо нормативних документах банку.

До основних зовнішніх фракторів можна віднести погіршення економічного стану в країні, зміни в політичній ситуації та зміни у законодавстві, недобросовісна конкуренція.

З'ясувавши передумови виникнення непрацюючого кредиту, можна умовно класифікувати проблемних боржників на чотири групи:

- Першою групою $є$ шахраї - ще люди які беручи кредит уже знають що віддавати його вони не будуть, зазвичай такі люди відсіюються на етапі верифрікації кредитної операції, про те деяким все ж видають гроші. Також до шахрайських дій можна віднести випадки надання позичальником до банку документи які не відповідають їх поточному фінансовому стану в надії на отримання позики на вигідніших умовах або за спеціальними програмами що не передбачені для них. Як наслідок існує висока ймовірність того що клієнт не зможе в повному обсязі виконувати взяті на себе обов'язки. До їх числа належить приблизно 10-15\% проблемних клієнтів

- До другої групи входять позичальники що у зв'язку із погіршенням фрінансового стану або настанням інших непередбачуваних ситуації не можуть повністю виконувати взяті на себе зобов'язання. Частка таких клієнтів становить близько 30-40\%.

- Третя група - це суб'єкти економічної діяльності які сподіваються на відсутність санкцій чи неуважність банківських працівників, таких людей не так багато 5-10\%.

- В четверту групу входять ті хто просто забувають вчасно здійснювати платежі по кредитах і у зв'язку із цим в них виникае прострочена заборгованість, таких близько 30-40\%. Зазвичай до четвертої групи входять фрізичні особи, оскільки в юридичних осіб є фрінансові відділи або бухгалтерія, що контролюе вчасність та повноту оплати кредитних коштів [3].

Банківським установам все одно через яку причину їм не повертають позикові кошти - через погіршення ситуації на ринку, через шахрайські дії третіх осіб або неуважність позичальника. Кожну затримку в поверненні кредитних коштів, або відмову в поверненні банк фріксує і передає в бюро кредитних історій (БКI). А отже фракти неповернення кредиту і ухилення від виконання умов кредитних договорів фріксуються в БКІ, і коли клієнт прийде до іншого банку за позикою існуе висока вірогідність що він отримае відмову у зв’язку із його ненадійністю.

Для попередження виникнення проблемної заборгованості кредитний моніторинг діє за такими напрямками: перевірка цільового використання, оцінка фрінансового стану позичальника, переоцінка та контроль за збереженням об'єкта застави, своєчасність погашення відсотків та основної суми боргу, дотриманням додаткових умов кредитного договору. У разі коли у клієнта погіршуеться фінансовий стан, він починає затримувати платежі по кредиту або він не дотримується взяти на себе не фрінансових зобов'язань кредитний моніторинг зобов'язаний передати інформацію кредитному менеджеру та у підрозділ роботи з проблемною заборгованістю.

Аналізуючи надійність позичальників та майбутніх клієнтів також слід звертати увагу на те що за умови стабільної економічної ситуації як у країні так і в світі в цілому завжди є можливість визначити основні чинники, які забезпечують прибуткову діяльність підприемства та можливість виконувати взяті на себе фрінансові зобов'язання. Про те коли економічна ситуація в країні або в світі стає нестабільною з'являеться проблема ощінки ризиків, оскільки класичні критерії ощінки ризиків полягають в екстраполяції та аналізі минулих або нинішніх тенденцій розвитку підприемства. У випадку, коли бізнес є стійким до зовнішніх потрясінь і погашає всі взяті на себе фрінансові зобов'язання вчасно та у повному обсязі, його кредитна історія буде бездоганною. Проте, як 
було сказано вище, будь-яке невиконання взятих на себе кредитних зобов'язань буде зафіксовано в кредитній історії. Саме тому крім ідентифікації відхилень в кредитній історії позичальника банкам необхідно проводити аналіз причин, які призвели до виникнення проблем з дотриманням умов договору, та враховувати ризики повторного настання подій що привили до про строчок із сторони клієнта.

Цільове використання кредитних коштів перевіряться для підтвердження напряму руху позикових коштів. Зазвичай при укладені кредитного договору обумовлюються цілі на які ці кошти можуть потрачені. Для підтвердження відповідності використання кредитних коштів використовуються фрінансові документи, такі як платіжні доручення, рахунки фрактури, митні декларації, акти прийому передачі, техпаспорти, витяги 3 державного реєстру нерухомого майна, укладенні договори, митні декларації та інші документи що згідно кредитного договору можуть підтвердити цільове використання грошей [4].

Якщо говорити про ощінку фрінансового стану позичальника потрібно звернути увагу на нормативні акти НБУ. Так у постанові НБУ від 30.06.2016 № 351 «Положення про визначення банками України розміру кредитного ризику за активними банківськими операціями» наводяться основні необхідні рекомендації для оцінки фрінансового стану клієнта. Крім того зазначені головні показники на які банк повинен звернути увагу при видачі кредитних коштів: прибутковість; рентабельність; рух грошових кошті по рахунках; ринкові умови при яких здійснюеться діяльність; склад та динаміка кредиторської та дебіторської заборгованості; наявність замовлень в тому числі державних та підтримка клієнта з боку держави; минула кредитна історія; якість, вартість та ліквідність заставного майна; ділова репутація клієнта та його пов'язаних осіб та ін. [5].

При проведенні моніторингу фрінансового стану позичальника в плановому порядку, а не при видачі кредитних коштів, використовуеться фрінансова звітність, довідки про кредити та обороти в інших банках, балансові довідки та розшифрровки рядків фрінансової звітності. На основі отриманих даних від позичальника банк оновлюе його клас. Юридичні особи з залежності від свого інтегрального показника фінансового стану та з урахуванням величини підприемства можуть отримати від першого по дев'ятий клас. Тобто клас позичальника формуеться на основі оцінки ймовірності його дефолту, розподіл банківських кредитів повинен бути обгрунтований та документально підкріплений. Чим вищий клас позичальника тим більші ризики неповернення кредитних коштів несе банк. Для успішного фрункціонування банк не повинен допускати високої концентрації клієнтів що мають високий клас а відповідно великі шанси дефолту.

Крім фонансових показників на величину кредитних ризиків також впливае вчасність та повнота дотримання додаткових умов кредитного договору, поточний стан та вартість заставного майна, вчасність переукладення страхових договорів та інші фрактори.

Нормативною базою проведення моніторингу кредитних операцій $є$ внутрішньо-нормативні документи банку з питань проведення моніторингу це програми, правила, методики та інші документи 3 питань моніторингу що затверджені в банку згідно з чинним законодавством України [6].

Загалом кредитний моніторинг можна розділити на шість етапів:

1. Кредитний моніторинг на рівні окремих позичальників.

2. Портфельний кредитний моніторинг.

3. Оцінка показників кредитних ризиків, визначення інтегрального показника.

4. Спостереження за змінами інтегрального показника.

5. Пошук та оцінка негативних тенденцій кредитних ризиків.

6. Вибір та впровадження методів управління кредитними ризиками [7].

Для того щоб банк міг якісно здійснювати моніторинг кредитних операцій необхідно створити підрозділ кредитного моніторингу який повинен контролювати якість обслуговування кредитів, виконання додаткових умов, цільове використання кредитних коштів, збір та аналіз фрінансових документів, визначення класу боржника та інші фрункції які покладе на підрозділ правління банку (рис. 2).

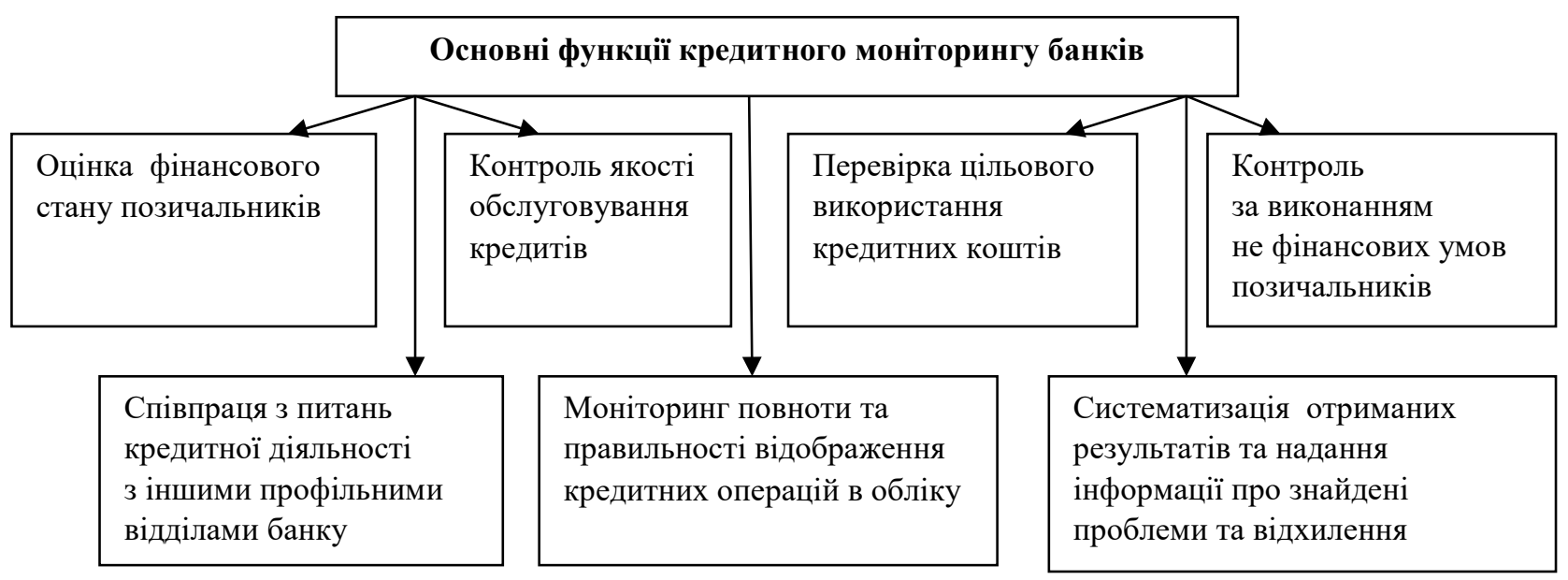

Рис. 2. Основні функції кредитного моніторингу банків 
Мета ж кредитного моніторингу полягає в недопущенні підвищення рівня кредитних ризиків понад встановлену правлінням банку та чинними нормативними актами НБУ норму. Сам кредитний моніторинг повинен відбувається безперервно, особлива увага повинна приділятись проведенню періодичної перевірки фінансового стану, для того щоб визначити клас позичальника та сдормувати відповідний резерв відшкодування витрат у разі неплатежів кліента по кредитним операціям [8].

Таким чином для оцінки кредитного ризику та його управлінням повинен існувати окремий підрозділ, оскільки адекватна та достовірна ощінка кредитного ризику клієнта це складне питання. Недостатній рівень кредитного моніторингу може в майбутньому призвести до значних збитків.

Висновки. Наведені матеріали показують зростання значимості впровадження у практику банківських установ адаптивної до сучасних умов системи моніторингу. Ця система за своєю функціональною роллю спрямована на забезпечення едективного банківського кредитування, яке залежить від адекватних і зрозумілих положеннях кредитних договорів на яких базуються відносини позичальника та кредитора. Саме завдяки правильно прописаним умовам кредитного договору в банка є можливість вчасно здійснювати моніторинг фрінансового стану кліента, що в свою чергу знижує ризик виникнення непередбачуваних ситуацій шляхом аналізу та контролю діяльності учасників позикової операції.

Загалом можна зробити висновок, що ефрективність кредитування банками залежить від структури кредитів, а тому на етапі моніторингу кредитних ризиків важливим є визначення сегментів що можуть стати проблемними і попередження виникнення непрацюючих кредитів. Ефективна діяльність служби кредитного моніторингу в банку є гарантом виконання завдань та досягнення цілей які прямо та опосередковано впливають на кредитні ризики банку та формування резервів. Моніторинг кредитних операцій займає одне 3 ключових місць в системі банківського кредитування та завжди потребуе пошуку нових шляхів вдосконалення.

\section{Список літератури:}

1. Сайт НБУ. URL: https://bank.gov.ua/ua/stability/npl

2. Белоглазова Г.Н., Кроливецкая Л.П. Банковское дело. Организация деятельности коммерческого банка : учебник. Москва : Юрайт, 2011. 422 с.

3. Болгар Т.М. Удосконалення моніторингу банківського кредитного процесу. Академічний огляд. 2013. № 2(39). C. 36-42

4. Штефан Л.Б. Проблеми управління кредитним ризиком в комерційних банках України. Ебективна еконоліка. 2015. № 3 .

5. Постанова НБУ «Про затвердження Положення про визначення банками України розміру кредитного ризику за активними банківськими операціями» від 30.06.2016 № 351.

6. Рац О.М. Організаційні засади кредитного моніторингу позичальників в системі управління кредитними ризиками банку. Науковий вісник Херсонського державного університету. 2014. № 5. С. 117-120

7. Гаряга Л.О. Моніторинг кредитного ризику в банківській діяльності : автореф. дис. на здобуття наук. ступеня канд. ек. наук : спец. 08.00.08 «Гроші, фрінанси і кредит». Суми, 2009. 22 с.

8. Халіменко Ю.А., Семениченко Ю.М. Оптимальний розподіл функціональних повноважень працівників банку з обслуговування кредитних операцій із суб’ектами господарювання. Вісник НБУ. 2010. № 11. С. 56-61.

\section{References:}

1. Official website of the NBU. URL: https://bank.gov.ua/ua/stability/npl

2. Belohlazova H.N., Krolyvetskaia L.P. (2011) Bankovskoe delo. Orhanyzatsyia deiatelnosty kommercheskoho banka [Banking. Organization of a commercial bank]: Textbook. Moscow: Yurait, $422 \mathrm{p}$.

3. Bolhar T.M. (2013) Udoskonalennia monitorynhu bankivskoho kredytnoho protsesu [Improving monitoring of bank credit process]. Akademichnyi ohliad, no. 2(39), pp. 36-42.

4. Shtefan L.B. (2015) Problemy upravlinnia kredytnym ryzykom v komertsiinykh bankakh Ukrainy [Problems of credit risk management in commercial banks Ukraine] Effective economy, no. 3.

5. Resolution of the NBU «Pro zatverdzhennia Polozhennia pro vyznachennia bankamy Ukrainy rozmiru kredytnoho ryzyku za aktyvnymy bankivskymy operatsiiamy» [On Approval of the Regulation on the Definition of Banks of Ukraine Credit Risk in Active Banking Operations] since 30.06.2016 no. 351.

6. Rats O.M. (2014) Orhanizatsiini zasady kredytnoho monitorynhu pozychalnykiv v systemi upravlinnia kredytnymy ryzykamy banku [Organizational principles of credit monitoring borrowers in the management of credit risk of the bank]. Scientific Bulletin of the Kherson State University, no. 5, pp. 117-120.

7. Hariaha L.O. (2009) Monitorynh kredytnoho ryzyku v bankivskii diialnosti [Monitoring credit risk using the integral index]: author's abstract. dis. for science gain. degree to the candidate. ec. sciences: special. 08.00.08 «Money, Finance and Credit». Sumy, $22 \mathrm{p}$.

8. Khalimenko Yu.A., Semenychenko Yu.M. (2010) Optymalnyi rozpodil funktsionalnykh povnovazhen pratsivnykiv banku z obsluhovuvannia kredytnykh operatsii iz subiektamy hospodariuvannia [Optimal distribution of functional powers of bank employees for servicing credit transactions with business entities]. Visnyk NBU, no. 11 , pp. 56-61. 